\title{
Synthesis, Spectral and Thermal Studies, and Crystal Structure of cis-Bis(4-methylimidazole)bis(picolinato)copper(II) $\left[\mathrm{Cu}(\text { pic })_{2}(4-\mathrm{MeIm})_{2}\right]$
}

\author{
Zerrin Heren ${ }^{\mathrm{a}}$, Cem Keser ${ }^{\mathrm{a}}$, C. Cüneyt Ersanlı ${ }^{\mathrm{b}}$, O. Zafer Yeşilel ${ }^{\mathrm{c}}$, and Nazan Ocak ${ }^{\mathrm{b}}$ \\ a Ondokuz Mayis University, Faculty of Arts and Sciences, Department of Chemistry, \\ TR-55139, Kurupelit, Samsun, Turkey \\ b Ondokuz Mayis University, Faculty of Arts and Sciences, Department of Physics, \\ TR-55139, Kurupelit, Samsun, Turkey \\ c Eskişehir Osmangazi University, Faculty of Arts and Sciences, Department of Chemistry, \\ TR-26480, Eskişehir, Turkey
}

Reprint requests to Dr. Z. Heren. E-mail: zheren@omu.edu.tr

Z. Naturforsch. 61b, 1217 - 1221 (2006); received February 20, 2006

The mixed-ligand picolinato (pic) complex of $\mathrm{Cu}(\mathrm{II})$ with 4-methylimidazole (4-MeIm), $\left[\mathrm{Cu}(\mathrm{pic})_{2}(4-\mathrm{MeIm})_{2}\right]$, was synthesized and characterized by elemental analysis, magnetic susceptibility, spectroscopic methods (UV/vis and FT-IR) and X-ray diffraction. In the slightly distorted octahedral cis-bis(4-methylimidazole)bis(picolinato)copper(II) complex, the pic ligands are coordinated to the $\mathrm{Cu}(\mathrm{II})$ ion as bidentate $N, O$-donors forming chelate rings. The 4-MeIm ligands are $N$-coordinated in cis positions. The complex crystallizes in the triclinic space group $P \overline{1}$ with unit cell parameters $a=9.204(5), b=9.498(5), c=13.095(5) \AA, \alpha=90.395(5), \beta=101.687(5), \gamma=112.291(5)^{\circ}$ and $Z=2$. Hydrogen bondings and C-H $\cdots \pi$ interactions occur between picolinato and methylimidazole ligands of neighboring complex molecules. The thermal decomposition of the complex is described.

Key words: Copper(II) Complex, 4-Methylimidazole, Picolinic Acid, Thermal Decomposition

\section{Introduction}

Pyridinecarboxylic acids and their derivatives are present in many natural products. They are of special interest to medicinal chemists because of the wide variety of physiological properties displayed by the natural and also many synthetic derivatives [1]. For example, picolinic acid is one of the metabolites of tryptophan [2]. Picolinic acid (pyridine 2-carboxylic acid, pic) is the body's prime natural chelator. The picolinato ligand is able to chelate metal ions and can display widely varying coordination modes as a multidentate ligand. It is the most efficient chelator for metal ions such as chromium, zinc, manganese, copper, iron and molybdenum in body fluids. Chromium picolinate favors the function of insulin, regulating blood sugar, diminishing cholesterol and fat and increasing muscle mass. It increases and regulates the secretion of insulin, such that glucose is better used and the amino acids are better absorbed [3,4]. Zinc picolinate has a healing effect against Herpes Simplex virus [5]. One of the ways to understand the chemistry and properties of picolinic acid is to study the structures of its metal complexes [4-7]. Imidazole derivatives are very important model molecules since the imidazole ring occurs in a series of biological molecules such as in histidine, in Vitamin $\mathrm{B}_{12}$ and biotin as well as in many chemotherapic agents [8].

In this paper, we describe the preparation and the characterization by FT-IR and electronic measurements, thermal analyses data (TG and DTA) and crystal structure determination of the cis-bis(4-methylimidazole)bis(picolinato)copper(II) complex.

\section{Results and Discussion}

IR spectrum

The IR spectrum of the complex exhibits a medium intensity and broad band in the $3093-2960 \mathrm{~cm}^{-1}$ region which can be attributed to the N-H stretching vibration of 4-MeIm. The strong and broad bands appearing in the $1632-1381 \mathrm{~cm}^{-1}$ region are attributed to the asymmetric and symmetric stretching vibrations of the coordinated carboxylate groups of the picolinato ligand. Such absorptions have already been reported and the positions of these bands have been well described in text books and articles [9-11]. Separation between asymmetric and symmet- 
ric stretching frequencies of $251 \mathrm{~cm}^{-1}$ is in agreement with a monodentate coordination mode for the carboxylate groups [9]. This is in good agreement with the results obtained from X-ray diffraction measurements. In the complex, the band at $1567 \mathrm{~cm}^{-1}$ can be attributed to the $(-\mathrm{C}=\mathrm{N}-)$ stretching vibration. The $\mathrm{M}-\mathrm{O}$ stretching vibration of the complex is observed at $419 \mathrm{~cm}^{-1}$.

\section{UV/vis spectrum and magnetic susceptibility}

The electronic spectrum of $\left[\mathrm{Cu}(\text { pic })_{2}(4-\mathrm{MeIm})_{2}\right]$ in water exhibits a broad absorption band at $641 \mathrm{~nm}$ ( $\varepsilon=42.0 \mathrm{Lmol}^{-1} \mathrm{~cm}^{-1}$ ) due to a $d-d$ transition. This $\lambda_{\max }$ value was assigned to the ${ }^{2} E_{g} \rightarrow{ }^{2} T_{2 g}$ transition. The $\Delta_{\mathrm{o}}$ value for the complex was calculated as $15,600 \mathrm{~cm}^{-1}$, since there is only one transition for $d^{9}$ complexes [12]. The absorption bands below $300 \mathrm{~nm}$ are due to intra-ligand transitions.

The magnetic susceptibility value of the complex is $\mu_{\text {eff }}=1.79 \mathrm{BM}$ corresponding to one unpaired electron.

\section{Thermal analysis}

Thermal analysis curves of the complex (TG and DTA) are given in Fig. 1. The thermal behavior of the complex was followed up to $600{ }^{\circ} \mathrm{C}$ in a static air atmosphere. The complex is thermally stable up to $167{ }^{\circ} \mathrm{C}$. The decomposition begins with melting at $172{ }^{\circ} \mathrm{C}$ (DTA peak) and reveals a $25.8 \%$ mass loss between 167 and $290{ }^{\circ} \mathrm{C}$. At this stage the elimination of the 4-methylimidazole ligands and the decomposition of the picolinato ligands with release of $\mathrm{CO}_{2}$ proceed. The IR spectrum of the intermediate product obtained in this step showed that the picolinato ligand indeed has decomposed with release of $\mathrm{CO}_{2}$. A good

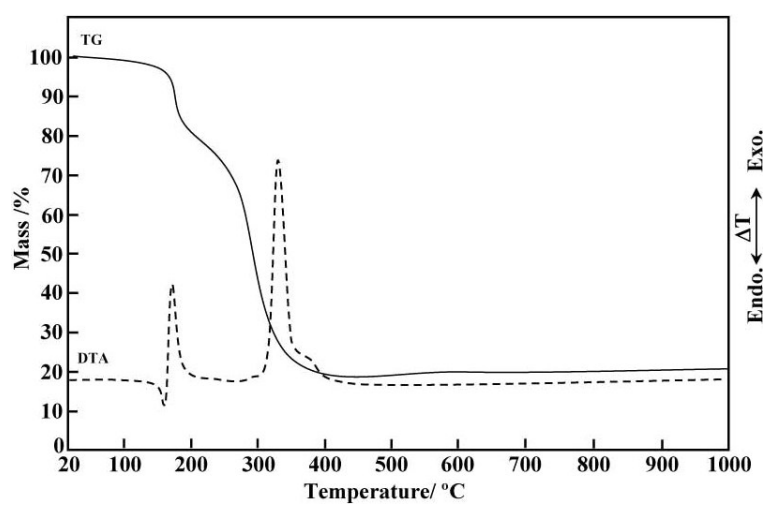

Fig. 1. The TG and DTA curves of $\left[\mathrm{Cu}(\text { pic })_{2}(4-\mathrm{MeIm})_{2}\right]$. agreement between the experimental and calculated values was observed for the mass loss (found 25.8\%; calcd. 26.8\%). The strong exothermic peak at $340{ }^{\circ} \mathrm{C}$ is associated with the burning of the organic residue (found $\mathrm{Cu} 81.8$; calcd. 83.2\%). The final decomposition product $\mathrm{CuO}$ was identified by IR spectroscopy.

\section{Crystallography}

$\pi-\pi$ Stacking between aromatic rings is correlated with the electron-transfer process in some biological systems [13]. Several metal complexes are known to incorporate imidazole rings [14]. The crystal structure of the copper(II) complex shows no $\pi$ - $\pi$ stacking between imidazole rings.

The molecular structure is shown in Fig. 2 and the crystallographic data are summarized in Table 1. Tables 2 and 3 list bond lengths and angles and hydrogen-bonding parameters. The $\mathrm{Cu}$ (II) atom has a slightly distorted octahedral coordination geometry formed by 4-methylimidazole and picolinato ligands (Table 2). The $\mathrm{Cu}-\mathrm{O}$ bond lengths of $\mathrm{Cu} 1-\mathrm{O} 1=2.325(1), \mathrm{Cu} 1-\mathrm{O} 3=2.307(1) \AA$ are in reasonable agreement with the values found in [15]. As shown in Table 2, the lengths of the $\mathrm{Cu}-\mathrm{N}$ bonds [2.000(2) and 2.069(2) $\AA$ ] are similar to other values reported in the literature [16]. The coordination of copper(II) clearly shows the geometrical pattern typi-

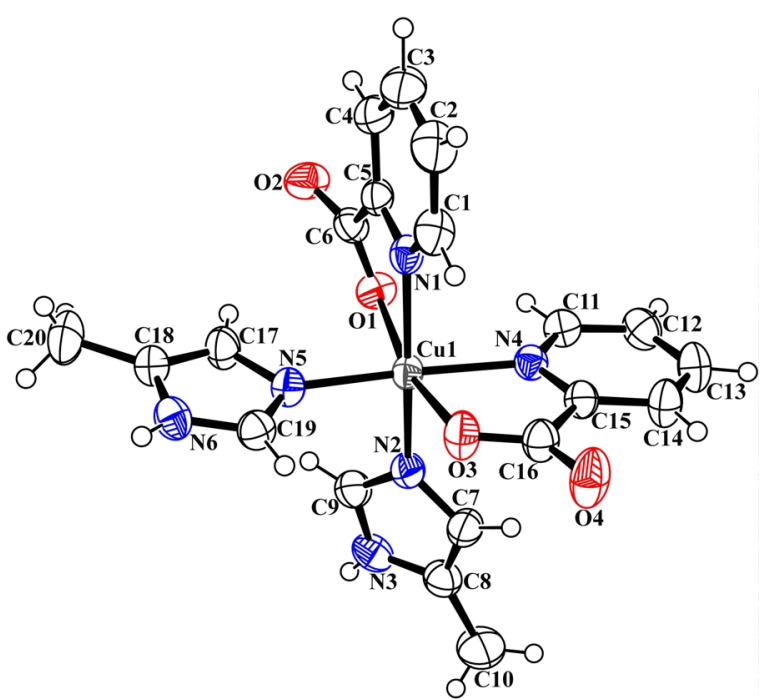

Fig. 2. A view of the copper coordination, with the atom labeling scheme. Displacement ellipsoids are drawn at the 50\% probability level and $\mathrm{H}$ atoms are shown as small spheres of arbitrary radii. 
Table 1. Crystal data and structure refinement parameters for $\left[\mathrm{Cu}(\text { pic })_{2}(4-\mathrm{MeIm})_{2}\right]$.

\begin{tabular}{|c|c|}
\hline Formula & $\mathrm{C}_{20} \mathrm{H}_{20} \mathrm{~N}_{6} \mathrm{O}_{4} \mathrm{Cu}$ \\
\hline Color & blue \\
\hline Molecular weight & 471.96 \\
\hline Temperature $(\mathrm{K})$ & 296 \\
\hline Wavelength $(\AA)$ & 0.71069 Mo-K $\alpha$ \\
\hline Crystal system & triclinic \\
\hline Space group & $P \overline{1}$ \\
\hline \multicolumn{2}{|l|}{ Unit cell dimensions } \\
\hline$a(\AA)$ & $9.204(5)$ \\
\hline$b(\AA)$ & $9.498(5)$ \\
\hline$c(\AA)$ & $13.095(5)$ \\
\hline$\alpha\left(^{\circ}\right)$ & $90.395(5)$ \\
\hline$\beta\left(^{\circ}\right)$ & $101.687(5)$ \\
\hline$\gamma\left({ }^{\circ}\right)$ & $112.291(5)$ \\
\hline Volume $\left(\AA^{3}\right)$ & $1032.8(9)$ \\
\hline$Z$ & 2 \\
\hline Calculated density $\left(\mathrm{Mgm}^{-3}\right)$ & 1.518 \\
\hline$\mu\left(\mathrm{mm}^{-1}\right)$ & 1.098 \\
\hline Crystal size (mm) & $0.52 \times 0.48 \times 0.33$ \\
\hline$\Theta$ Range for data collection & $2.3-28.0^{\circ}$ \\
\hline \multicolumn{2}{|l|}{ Index ranges } \\
\hline$h$ & $-11 \rightarrow 11$ \\
\hline$k$ & $-11 \rightarrow 11$ \\
\hline$l$ & $-14 \rightarrow 16$ \\
\hline Reflections collected & 14918 \\
\hline Independent reflections & $3717\left(R_{\mathrm{int}}=0.025\right)$ \\
\hline Reflections observed $(\geq 2 \sigma)$ & 4051 \\
\hline Absorption correction & integration \\
\hline Max. and min. Transmission & 0.594 and 0.704 \\
\hline Refinement method & $F^{2}$ \\
\hline$w$ & $\begin{array}{l}1 /\left[2 \sigma\left(F_{\mathrm{o}}^{2}\right)+(0.0325 P)^{2}+0.3985 P\right] \\
\text { where } P=\left(F_{\mathrm{o}}^{2}+2{F_{\mathrm{c}}}^{2}\right) / 3\end{array}$ \\
\hline Goodness-of-fit on $F^{2}$ & 1.03 \\
\hline$R\left[F^{2} \geq 2 \sigma\left(F^{2}\right)\right]$ & 0.025 \\
\hline$w R\left(F^{\overline{2}}\right)$ & 0.066 \\
\hline $\begin{array}{l}\text { Largest diff. peak } \\
\quad \text { and hole }\left(\mathrm{e} \AA^{-3}\right)\end{array}$ & $0.24,-0.33$ \\
\hline
\end{tabular}

Table 2. Selected bond lengths $(\AA)$ and bond angles $\left({ }^{\circ}\right)$ for $\left[\mathrm{Cu}(\mathrm{pic})_{2}(4-\mathrm{MeIm})_{2}\right]$.

\begin{tabular}{llll}
\hline $\mathrm{Cu}(1)-\mathrm{N}(1)$ & $2.069(2)$ & $\mathrm{Cu}(1)-\mathrm{O}(3)$ & $2.307(1)$ \\
$\mathrm{Cu}(1)-\mathrm{N}(2)$ & $2.000(2)$ & $\mathrm{C}(9)-\mathrm{N}(2)$ & $1.318(2)$ \\
$\mathrm{Cu}(1)-\mathrm{N}(4)$ & $2.052(2)$ & $\mathrm{C}(19)-\mathrm{N}(5)$ & $1.314(2)$ \\
$\mathrm{Cu}(1)-\mathrm{N}(5)$ & $2.015(2)$ & $\mathrm{C}(7)-\mathrm{C}(8)$ & $1.350(3)$ \\
$\mathrm{Cu}(1)-\mathrm{O}(1)$ & $2.325(1)$ & $\mathrm{C}(17)-\mathrm{C}(18)$ & $1.351(3)$ \\
$\mathrm{N}(2)-\mathrm{Cu}(1)-\mathrm{N}(5)$ & $92.0(1)$ & $\mathrm{N}(1)-\mathrm{Cu}(1)-\mathrm{O}(3)$ & $94.0(1)$ \\
$\mathrm{N}(2)-\mathrm{Cu}(1)-\mathrm{N}(4)$ & $90.2(1)$ & $\mathrm{N}(2)-\mathrm{Cu}(1)-\mathrm{O}(1)$ & $93.4(1)$ \\
$\mathrm{N}(5)-\mathrm{Cu}(1)-\mathrm{N}(4)$ & $172.0(1)$ & $\mathrm{N}(5)-\mathrm{Cu}(1)-\mathrm{O}(1)$ & $91.8(1)$ \\
$\mathrm{N}(5)-\mathrm{Cu}(1)-\mathrm{N}(1)$ & $90.4(1)$ & $\mathrm{N}(4)-\mathrm{Cu}(1)-\mathrm{O}(1)$ & $95.7(1)$ \\
$\mathrm{N}(4)-\mathrm{Cu}(1)-\mathrm{N}(1)$ & $88.9(1)$ & $\mathrm{N}(1)-\mathrm{Cu}(1)-\mathrm{O}(1)$ & $75.9(1)$ \\
$\mathrm{N}(2)-\mathrm{Cu}(1)-\mathrm{O}(3)$ & $96.4(1)$ & $\mathrm{O}(3)-\mathrm{Cu}(1)-\mathrm{O}(1)$ & $167.1(1)$ \\
$\mathrm{N}(5)-\mathrm{Cu}(1)-\mathrm{O}(3)$ & $96.3(1)$ & & \\
\hline
\end{tabular}

cal for the Jahn-Teller effect. The Cu1-N1 and Cu1-N4 distances are shorter than the $\mathrm{Cu} 1-\mathrm{O} 1$ and $\mathrm{Cu} 1-\mathrm{O} 3$ distances, and this results in the formation of a distorted
Table 3. Hydrogen bonding parameters $\left(\AA{ }^{\circ}\right)$.

\begin{tabular}{lllll}
\hline D-H $\cdots$ A & D-H & H $\cdots A$ & D $\cdots A$ & D-H $\cdots A$ \\
\hline N3-H3N $\cdots$ O 2 & \\
ii & $0.74(2)$ & $2.01(2)$ & $2.750(2)$ & $171(2)$ \\
N6-H6N $\cdots$ O 4 & $0.76(3)$ & $1.98(3)$ & $2.744(2)$ & $177(3)$ \\
\hline Symmetry codes: ${ }^{\text {i }} 1-x, 1-y,-z$ & ii $1-x, 1-y, 1-z$ &
\end{tabular}

Symmetry codes: ${ }^{\mathrm{i}} 1-x, 1-y,-z ;{ }^{\mathrm{ii}} 1-x, 1-y, 1-z$.

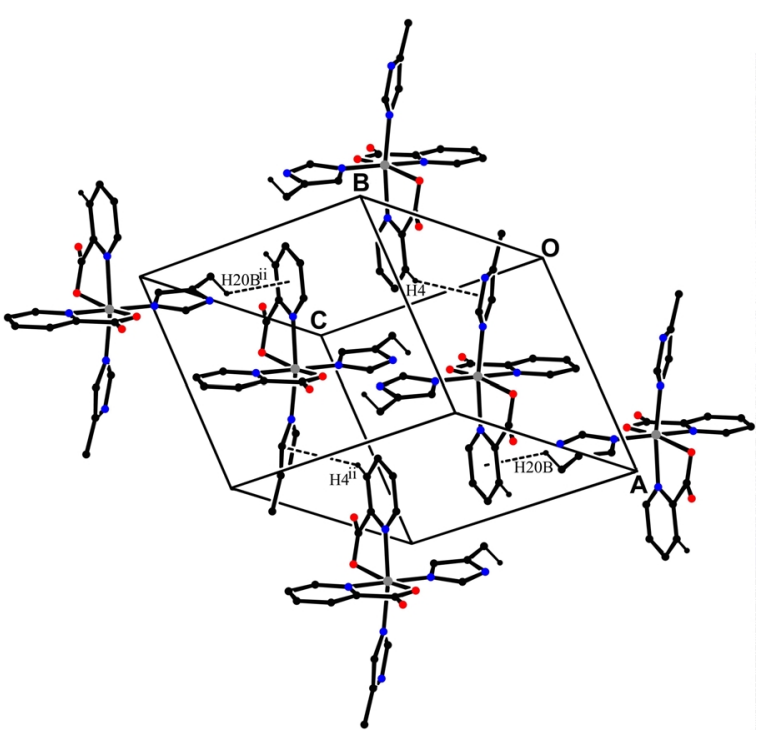

Fig. 3. Diagram of the $\mathrm{C}-\mathrm{H} \cdots \pi$ interactions (dashed lines). $\mathrm{H}$ atoms not involved in $\mathrm{C}-\mathrm{H} \cdots \pi$ interactions have been omitted for clarity [symmetry code: ${ }^{\text {ii }} 1-x, 1-y, 1-z$ ].

octahedral geometry elongated along the $\mathrm{N}$ atoms. This effect is usually observed for analogous compounds, such as catena-poly[[(1,10-phenanthroline$\left.\kappa^{2} N, N^{\star}\right)$ copper(II)]- $\mu$-4-carboxyimidazole-5-carboxylato(2-)- $\left.\kappa^{4} N, O: N^{\star}, O^{\star}\right] \quad[17][\mathrm{Cu} 1-\mathrm{N} 3=2.007(3)$ and $\mathrm{Cu} 1-\mathrm{O} 1=2.383(3) \AA]$ and chloro(methylpicolinato- $N, O)$ (picolinato- $N, O)$ copper(II) [18] [Cu1$\mathrm{N} 2=2.006(2)$ and $\mathrm{Cu} 1-\mathrm{O} 3=2.390(2) \AA]$.

The title complex contains two picolinato rings and two imidazole rings. The two imidazole rings are individually planar, with r.m.s. deviations of $0.002 \AA$, with maximum deviations from these planes of 0.002(2) $\AA$ for atom C8 and of 0.003(2) $\AA$ for atom C19. These planes are approximately perpendicular, with a dihedral angle of $85.7(1)^{\circ}$. The dihedral angles between the picolinato ring (containing N4) and the imidazole groups are $82.7(1)$ and $8.0(1)^{\circ}$. The internal geometries are as expected, with the bond lengths

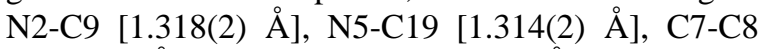

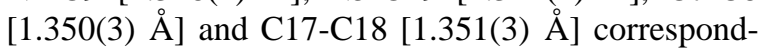
ing to typical double-bond lengths. These values are comparable with those in mixed-ligand imidazole$\mathrm{Cu}(\mathrm{II})$ complexes $[19,20]$. The two picolinato rings 
are individually planar, with r.m.s. deviations of 0.002 and $0.003 \AA$, and with maximum deviations from these planes of 0.011(2) $\AA$ for atom C3 and 0.010(3) $\AA$ for atom $\mathrm{C} 13$. These planes are approximately perpendicular, with a dihedral angle of $89.0(1)^{\circ}$. The dihedral angles between the picolinato ring (containing N1) and the imidazole groups are 40.3(1) and 86.6(1) ${ }^{\circ}$.

The crystal packing of the title complex is formed via intermolecular hydrogen bonds and $\pi$-ring interactions. Carboxyl atoms $\mathrm{O} 2$ and $\mathrm{O} 4$ are hydrogen bonded to the picolinato ligands of a neighboring complex molecule (Table 3). A PLATON analysis [21] shows that $\mathrm{C}-\mathrm{H} . \ldots \pi$ interactions occur between the imidazole and neighboring picolinato rings (Fig. 3); C4-H4... Cg1 = 139(2) ${ }^{\circ}$ and $\mathrm{H} 4 \ldots \mathrm{Cg} 1=2.96(3) \AA$, where $\mathrm{Cg} 1$ denotes the centroid of the $\mathrm{N} 2 / \mathrm{N} 3 / \mathrm{C} 7-\mathrm{C} 9$ ring [symmetry code: (ii) $1-x, 1-y, 1-z]$ and $\mathrm{C} 20-\mathrm{H} 20 \mathrm{~B} \ldots \mathrm{Cg} 2=134(3)^{\circ}$ and $\mathrm{H} 20 \mathrm{~B} \ldots \mathrm{Cg} 2=2.82(4) \AA$, where $\mathrm{Cg} 2$ denotes the centroid of the N1/C1-C5 ring [symmetry code: (ii) $1-x, 1-y, 1-z]$. No $\pi-\pi$ stacking occurs between picolinato rings.

\section{Experimental Section}

Materials and measurements

All chemicals used were analytical reagent grade products. 4-Methylimidazole was obtained from Merck. Picolinic acid was purchased from ACROS organics.

Magnetic susceptibility measurements at r.t. were performed using a Sherwood Scientific MXI model Gouy magnetic balance. The UV/vis spectrum was obtained for the aqueous solution of the complex $\left(10^{-3} \mathrm{M}\right)$ with a Unicam UV2 spectrometer in the range $900-190 \mathrm{~nm}$. The IR spectrum was recorded in the $4000-400 \mathrm{~cm}^{-1}$ region with a Mattson 1000 FT-IR spectrometer using $\mathrm{KBr}$ pellets. A TG8110 thermal analyzer was used to record simultaneous TG and DTA curves in static air atmosphere at a heating rate of $10 \mathrm{Kmin}^{-1}$ in the temperature range $20-1000{ }^{\circ} \mathrm{C}$ using platinum crucibles. Highly sintered $\alpha-\mathrm{Al}_{2} \mathrm{O}_{3}$ was used as a reference and the DTG sensitivity was $0.05 \mathrm{mg} \mathrm{s}^{-1}$. The elemental analysis was carried out at the TÜBITAK Marmara Research Centre.

\section{Crystallographic analysis}

A blue single crystal suitable for data collection was mounted on a glass fiber and data collection was performed on a STOE IPDS-II diffractometer with graphite monochromated $\operatorname{Mo} K_{\alpha}$ radiation $(\lambda=0.71069 \AA)$ at $296 \mathrm{~K}$. Details of the crystal structure are given in Table 1. Data collection and cell refinement: STOE X-AREA [22]. Data reduction: STOE X-RED32 [22]. The structure was solved by Direct Methods using SHELXS-97 [23] and refined by full-matrix least-squares methods on $F^{2}$ using SHELXL-97 [23]. All non-hydrogen atoms were refined with anisotropic parameters. All $\mathrm{H}$ atoms were refined isotropically. The refined $\mathrm{C}-\mathrm{H}$ and $\mathrm{N}-\mathrm{H}$ bond lengths are in the ranges $0.83(4)-1.00(4)$ and 0.74(2)-0.76(3) ̊̊, respectively. Molecular drawings were obtained using ORTEP-III [24]. Software used to prepare material for publication: WinGX [25].

Crystallographic data (in cif files) for the structure reported in this paper have been deposited with the Cambridge Crystallographic Data Centre, CCDC No. 291470. Copies of this information may be obtained from the Director, CCDC, 12 Union Road, Cambridge CB2 1EZ, UK (fax: +44-1223-336033; e-mail: deposit@ccdc.cam.ac.uk or http://www.ccdc.cam.ac.uk).

\section{Preparation of [Cu(pic $\left.)_{2}(4-\mathrm{MeIm})_{2}\right]$}

The $\left[\mathrm{Cu}(\text { pic })_{2}\right] \cdot 2 \mathrm{H}_{2} \mathrm{O}$ complex was prepared by the method reported earlier [7]. A solution of 4-MeIm (4 mmol) in ethanol $\left(10 \mathrm{~cm}^{3}\right)$ was added dropwise with stirring to a solution of $\left[\mathrm{Cu}(\text { pic })_{2}\right] \cdot 2 \mathrm{H}_{2} \mathrm{O}(2 \mathrm{mmol})$ in ethanol $\left(20 \mathrm{~cm}^{3}\right)$. The solution was heated to $50{ }^{\circ} \mathrm{C}$ in a temperature-controlled bath and stirred for $4 \mathrm{~h}$. The reaction mixture was then cooled to r.t. The dark blue crystals formed were filtered off and washed with water and dried in air. Crystals suitable for $\mathrm{X}$-ray diffraction were obtained by slow diffusion of absolute ethanol into the filtrate. M.p. $172{ }^{\circ} \mathrm{C}$. $-\mathrm{UV} / \mathrm{vis}\left(\mathrm{H}_{2} \mathrm{O}\right)$ : $\lambda_{\max }(\lg \varepsilon)=641 \mathrm{~nm}(3.74) .-\mathrm{IR}(\mathrm{KBr}): \tilde{v}=3093(\mathrm{~N}-\mathrm{H})$, 1632, 1381, 1567, $419 \mathrm{~cm}^{-1}$. $-\mathrm{C}_{20} \mathrm{H}_{20} \mathrm{~N}_{6} \mathrm{O}_{4} \mathrm{Cu}$ (471.96): calcd. C 50.90, H 4.24, N 17.81; found C 50.72, H 4.27, $\mathrm{N} 17.54$.

\section{Acknowledgement}

The authors wish to acknowledge the Faculty of Arts and Sciences, Ondokuz Mayis University, Turkey, for the use of the STOE IPDS-II diffractometer (purchased under grant F.279 of the University Research Fund).
[1] K. A. Idriss, M. S. Saleh, H. Sedaira, M. M. Sleim, E. Y. Hashem, Monatsh. Chem. 122, 507 (1991).

[2] R. Song, K. M. Kim, Y.S. Sohn, Inorg. Chim. Acta 292, 238 (1999).
[3] T. L. Varadinova, P. R. Bontehev, C. K. Nachev, S. A. Shiskov, J. Chemotherapy. 5, 3 (1993).

[4] N.E. Chakov, R. A. Collins, J. B. Vincent, Polyhedron 22, 2891 (1999). 
[5] R. March, W. Clegg, R.A. Coxall, L. CucurullSánchez, L. Lezama, T. Rojo, P. González-Duarte, Inorg. Chim. Acta 353, 129 (2003).

[6] S. Basu, S.-M. Peng, G.-H. Lee, S. Bhattacharyya, Polyhedron, 24, 1, 157 (2005).

[7] R. Faure, H. Loiseleur, G. Thomas-David, Acta Crystallogr. B29, 1890 (1973).

[8] R. M. Achelson, Introduction to the Chemistry of Heterocylic Compounds, Wiley, New York (1986).

[9] K. Nakamato, Infrared and Raman Spectra of Inorganic and Coordination Compounds, p. 232, Wiley \& Sons, New York (1986).

[10] D. Sutton, Electrostatic Energy Level Diagrams and The Spectra of Octahedral Complexes. In Electronic Spectra of Transition Metal Complexes, p. 115, McGraw-Hill, London (1968).

[11] M. Rehakova, K. Jesenak, S. Nagyova, R. Kubinec, S. Cuvanova, V. S. Fajnor, J. Therm. Anal. Cal. 76, 139 (2004).

[12] D. Czakis-Sulikowska, A. Czylkowska, J. Therm. Anal. Cal. 76, 543 (2004).

[13] J. Deisenhofer, H. Michel, EMBO. J. 8, 2149 (1989).

[14] D.-D. Lin, K.-L. Yin, D.-J. Xu, Acta Crystallogr. E61, 260 (2005).

[15] H. Icbudak, H. Ölmez, O. Z. Yesilel, F. Arslan, P. Naumov, G. Jovanovski, A. R. Ibrahim, A. Usman, H. K.
Fun, S. Chantrapromma, S. W. Ng, J. Mol. Struct. 657, 255 (2003).

[16] H.-Y. Wang, S.-J. Liu, R.-J. Wang, C.-C. Su, Acta Crystallogr. C59, 512 (2003).

[17] C.-S. Gu, S. Gao, L.-H. Huo, H. Zhao, J.-G. Zhao, Acta Crystallogr. E60, 1852 (2004).

[18] M. Bhar, M. Chaudhury, E. R. T. Tiekink, Acta Crystallogr. E57, 305 (2001).

[19] T.-G. Xu, J.-G. Liu, D.-J. Xu, Acta Crystallogr. E61, 622 (2005).

[20] J. G. Díaz, J. Kožíšek, M. Fronc, A. Gatial, I. Svoboda, V. Langer, Acta Crystallogr. C61, 180 (2005).

[21] A. L. Spek, J. Appl. Crystallogr. 36, 7 (2003).

[22] Stoe \& Cie, X-AREA (version 1.18) and X-RED32 (version 1.04). Stoe \& Cie, Darmstadt, Germany (2002).

[23] G. M. Sheldrick, SHELXS-97 and SHELXL-97. Program for Crystal Structure Refinement, University of Göttingen, Germany (1997).

[24] M. N. Burnett, C.K. Johnson, ORTEP-III. Report ORNL-6895. OAK Ridge National Laboratory, Tennessee, U.S.A. (1996).

[25] L. J. Farrugia, WinGX Suite for Single Crystal Small Molecule Crystallography, J. Appl. Crystallogr. 32, 837 (1999). 